УДК 005.8

DOI 10.47049/2226-1893-2021-2-173-185

\title{
МЕХАНІЗМИ \\ ПРОЕКТНО-ОРІЄНТОВАНОГО УПРАВЛІННЯ ЗАКЛАДАМИ ВИЩОЇ ОСВІТИ В РАМКАХ ІННОВАЦЙНИХ ПРОГРАМ
}

\section{В.М. Пітерська}

доктор технічних наук, доцент, професор кафедри «Експлуатація портів і технологія вантажних робіт»

Одеський національний морський університет, Одеса, Украйна

Анотація. Актуальність дослідження обумовлена сучасним несприятливим інновачійним кліматом в державі, який сформований в умовах не прачюючого державного регулювання інноваційної сфери, стрімкого занепаду украйнської науки, ї̈ фактичної відірваності від підприємництва. У такій ситуаиії виникає нагальна необхідність розробки нових теоретичних $і$ методологічних підходів та механізмів на основі передового досвіду розвинутих краӥн, які б дозволили підвищити ефективність взаємодії учасників інновачійної діяльності, а саме закладів вищяої освіти, щуо займають найбільшу частку в сфері проведення наукової діяльності у державі. Було встановлено, щуо за останні десятиріччя українська наука зазнала значних змін. Колись одна з провідних країн світу з чисельними школами, традиціями, матеріально-технічними базами, Украӥна перетворилась на державу, в якій всі спроби на підвищення ефективності інноваційної діяльності закінчуються занепадом. Вказано, щзо несприятлива ситуація у науковій та інновачійній сфері набуває катастрофічного характеру, щзо може викликати несприятливі тенденції у забезпеченні технологічної та економічною безпеки України. Було запропоновано вирішення зазначеної проблеми із залученням провідних експертів та владних структур всіх рівнів. Без кардинального використання у системі управління науковою діяльністю закладів вищої освіти методології проектного менеджменту досягти результатів в сфері наукових досліджень та їх впровадження у виробництво неможливо.

Ключові слова: науковий проект, заклад вищої освіти, управління проектами.

УДК 005.8

DOI 10.47049/2226-1893-2021-2-173-185

\section{МЕХАНИЗМЫ \\ ПРОЕКТНО-ОРИЕНТИРОВАННОГО УПРАВЛЕНИЯ ЗАВЕДЕНИЯМИ ВЫСШЕГО ОБРАЗОВАНИЯ В РАМКАХ ИННОВАЦИОННЫХ ПРОГРАМ}

\section{В.М. Питерская}

доктор технических наук, доцент, профессор кафедры «Эксплуатация портов и технология грузовых работ»

Одесский нациинальный морской университет, Одесса, Украина

(C) Пітерська В.М., 2021 
ВІСНИК

ОДЕСЬКОГО НАЦІОНАЛЬНОГО

МОРСЬКОГО УНІВЕРСИТЕТУ № 2 (65), 2021
HERALD

OF THE ODESSA NATIONAL

MARITIME UNIVERSITY № 2 (65), 2021

Аннотация. Актуальность исследования обусловлена современным неблагоприятным инновационным климатом в государстве, который сформирован в условиях неработающего государственного регулирования инновачионной сфери, быстрого упадка украинской науки, ее фактической оторванности от предпринимательства. В такой ситуации возникает настоятельная необходимость разработки новых теоретических и методологических подходов и механизмов на основе передового опыта развитых стран, которые бы позволили повысить еффективность взаимодействия участников инновационной деятельності, а именно заведений высшего образования, которые занимают самую большую часть в сфере проведения научной деятельності в государстве. Было установлено, что за последние десятилетия украинская наука претерпела значительные изменения. Когда-то одна из ведущих стран мира с многочисленными школами, традиџиями, материально-техническими базами, Украина превратилась в государство, в котором все попытки повышения эффективности инновационной деятельности заканчиваются упадком. Указано, что неблагоприятная ситуация в научной u инновационной сферах приобретает катастрофический характер, что может вызвать неблагоприятные тенденции в обеспечении технологической и экономической безопасности Украины. Было предложено решение указанной проблемы с привлечением ведущих экспертов и властных структур всех уровней. Без кардинального использования в системе управления научной деятельностью заведений высшего образования методологии проектного менеджмента достичь результатов в сфере научных исследований и их внедрения в производство невозможно.

Ключевые слова: научный проект, заведение высшего образования, управление проектами.

UDC 005.8

DOI 10.47049/2226-1893-2021-2-173-185

\title{
MECHANISMS OF PROJECT-ORIENTED MANAGEMENT OF HIGHER EDUCATION INSTITUTIONS WITHIN THE FRAMEWORK OF INNOVATIVE PROGRAMS
}

\author{
Varvara Piterska \\ Doctor of Science (Engineering), Associate Professor, Professor at the Department \\ of «Port Operations and Cargo Works Technology» \\ ORCID ID: http:// orcid.org/0000-0001-5849-9033 \\ e-mail:varuwa@ukr.net \\ Odessa National Maritime University, Odessa, Ukraine

\begin{abstract}
The relevance of the research is due to the modern unfavorable innovation climate in the state, which was formed in the conditions of non-functioning state regulation of the innovation sphere, the rapid decline of
\end{abstract}


Ukrainian science, its actual isolation from entrepreneurship. In such a situation, there is an urgent need to develop new theoretical and methodological approaches and mechanisms based on the advanced experience of developed countries, which would make it possible to increase the efficiency of interaction between participants in innovative activities, namely, higher educational institutions that occupy the largest share in the field of scientific activities in the state. It was found that over the past decades, Ukrainian science has undergone significant changes. When one of the leading countries in the world with numerous schools, traditions, material and technical bases, Ukraine turned into a state in which all attempts to improve the efficiency of innovative activities end in decline. It is pointed out that the situation in the scientific and innovation spheres is becoming disastrous, which can cause unfavorable trends in ensuring the technological and economic security of Ukraine. A solution to this problem was proposed with the involvement of leading experts and government agencies at all levels. It is impossible to achieve results in the field of scientific research and their implementation in production without fundamental use of the project management methodology in the management system of scientific activities of higher educational institutions.

Keywords: research project, institution of higher education, project management.

Вступ. Основними центрами виконання наукової діяльності в Україні $є$ заклади вищої освіти (далі - ЗВО), витрати на проведення науково-дослідної діяльності в яких становлять $25 \%$ від загальних витрат на виконання наукових досліджень всіма науковими установами України. Кількість впроваджених інновацій і реалізованих інноваційних продуктів ЗВО залишається на критично низькому рівні та складає менше 4 \% від загальної кількості завершених наукових проектів. Однак, проблема не стільки в недостатності фінансування інноваційної діяльності, скільки в дуже низькій ефективності вкладених в науково-технічний розвиток коштів 3 причини відсутності адекватних сучасній ринковій економіці ланцюгів взаємозв'язку науки, технологій та виробництва.

Виходячи $з$ актуальності наявних в Україні проблем, вирішення яких потребує розроблення науково-обгрунтованих методів і моделей забезпечення розвитку інноваційної діяльності, пріоритетними напрямами державної політики має стати:

- в науковій галузі - фундаментальні та прикладні дослідження, система вищої освіти, підготовка та перепідготовка наукових, науковопедагогічних кадрів, забезпечення наукових основ розвитку соціальноорієнтованої ринкової економіки, наукове дослідження в області охорони здоров'я та екології, інформаційне та матеріально-технічне забезпечення наукової діяльності у закладах вищої освіти;

- у виробничій галузі - впровадження наукомістких виробничих технологій, стимулювання створенню інноваційних технопарків, інкуба- 
торів, створення конкурентоспроможних інноваційних виробництв; технологічне оновлення матеріально-технічної бази основних галузей економіки, реалізація високорентабельних інноваційних та інвестиційних проектів, реалізація яких сприятиме прогресивним змінам у структурі та тенденціях розвитку виробництва;

- у технологічній галузі - створення умов для високопродуктивної праці; розроблення механізмів та засобів захисту та охорони здоров'я; розробка ресурсо-, енергозберігаючих технологій;

- у фінансовій галузі - підвищення рівня державного фінансування науки, залучення до фінансування інноваційної діяльності бізнесових структур, дольове розподілення витрат між всіма учасниками інноваційної діяльності щодо розроблення і впровадження інноваційної продукції.

Стимулювання розвитку інноваційної діяльності не може обмежуватись лише одноразовим стимулюванням лише одного виду наукових досліджень чи розробок за рахунок бюджетного фінансування (пряме фінансування чи оподаткування).

Спроби здійснення галузевих «технологічних стрибків» за умов збереження загальної несприятливості підприємницького та інвестиційного клімату в країні, надмірного фіскального тиску, неефективності інституційної структури економіки обертаються втратами інших секторів економіки [1].

Продукція високотехнологічних галузей не знаходить збуту в інших галузях через великий технологічний відрив і відсутність мотивації використання, що істотно знижує синергетичний ефект інновацій, відтак ефективність таких «точок зростання» нівелюється у суспільному масштабі [1].

Державне стимулювання інновацій шляхом, наприклад, пільгового оподаткування наукової діяльності та інновацій, яке відірване від запровадження дієвих стимулів для інвестиційної діяльності, веде до марнування державних коштів та розриву між наукою і вітчизняним виробництвом.

Тому головним завданням інноваційної політики має стати збалансоване забезпечення взаємодії наукової, бізнесової та державної сфер, а також розроблення та впровадження механізму активізації інноваційної діяльності ЗВО, держави та суб'єктів підприємництва з метою поширення інновацій в усіх сферах національної економіки.

Відтак стратегія розвитку інноваційної діяльності має грунтуватися на:

- цілеспрямованій інвестиційній та промислові політиці держави, яка має бути спрямована на активізацію інноваційної діяльності як пріоритетної стратегії соціально-економічного розвитку країни та конкурентоспроможності бізнесових суб'єктів з метою забезпечення єдності інноваційної політики; 
- сприятливих інституційних умовах для інноваційної діяльності, а саме правової підтримки інноваційної діяльності, запровадження пільгового режиму оподаткування, а також удосконалення механізмів фінансування інновацій;

- підвищенні попиту на інноваційну продукцію, шляхом проведення ефективної маркетингової політики;

- забезпеченні ринкової інфраструктури для збільшення питомої ваги наукомістких продуктів у виробничому споживанні;

- реалізації підприємствами стратегії з освоєння світового ринку, підтримці конкуренції на національному ринку, яка сприятиме здійсненню інноваційної діяльності;

- забезпеченні співпраці 3ВО, державних органів, бізнесових структур з великими корпораціями;

- підтримці наукової діяльності в області забезпечення реалізації загальнодержавних інноваційних програм розвитку;

- посиленні інтеграції держави у світовий науково-технологічний простір;

- розширенні міжнародної співпраці в галузі інновацій.

Стратегія створення в Україні економічних засад інноваційної моделі розвитку передбачає комплекс заходів у податковій, бюджетній, грошово-кредитній, інституційній та зовнішньоекономічній сферах.

Важливим є приділення особливої уваги закладам вищої освіти, в яких працює найбільша кількість науковців, що займаються інноваційною діяльністю.

Аналіз основних досягнень і літератури. Дослідження, які проведені у [2], стосуються розробленню методів і моделей проектного управління при створенні наукомістких підприємств, які приймають активну участь в інноваційному розвитку держави.

В роботі [3] наведена модель гармонізації цінностей програм розвитку організацій в умовах турбулентного оточення. Механізми формування цінності в діяльності проектно-керованих організацій представлені в [4]. Проривні компетенції в управлінні інноваційними проектами та програмами наведені в роботах [5; 6]. Ціннісно-орієнтований аналіз прийняття рішень в управлінні проектами проведений в роботі [7]. Концепція вибору та формалізації проекту за відсутності повної інформації представлена в [8].

Концептуальні основи управління якістю в проектному менеджменті та 3 управління інноваційними проектами і програмами представлені в [9]. Формування цінності в діяльності проектно-орієнтованих організацій також проведено в роботі [10]. 
Дослідження, проведене в [11], присвячено розробці методологічних основ інноваційного проектно-орієнтованого управління організаціями. Запропонована в [12] енергетична модель дозволяє представити процес проектного управління на основі визначення цінностей організаціï.

Розробка методів оцінки, вимірювання, аналізу розвитку науковотехнічного рівню галузі, а також моделі управління портфелем проектів в умовах невизначеності представлено у працях [13]. Система стандартів підприємства для управління знаннями в проектно-керованій організації наведена в [14]. Інноваційні проекти формування інформаційної інфраструктури освітнього простору університету запропоновані в роботі [15].

Метою дослідження $\epsilon$ дослідження механізмів проектноорієнтованого управління закладами вищої освіти при реалізації інноваційних програм.

Матеріали дослідження. Аналіз обсягів фінансування наукової діяльності в академічному секторі, секторі вищої освіти, галузевому секторі, заводському секторі показує, що у 2020 р. найбільший обсяг коштів 2352,98 млн. грн. (71,9 \% від загального обсягу фінансування наукової діяльності; 79,1 \% - 2019 р.) спрямовано на академічний сектор науки [5].

Якщо розглядати кількісні показники результатів наукової діяльності, то найбільшу кількість інноваційної продукції у 2020 році було створено закладами вищої освіти [5].

Однак, якщо проаналізувати динаміку зміни витрат на проведення наукових досліджень Міністерством освіти і науки України та Національною Академією наук України можна з впевненістю стверджувати про неефективний розподіл фінансових ресурсів між установами, що займаються науковою діяльністю [6].

Найбільша кількість науковців (приблизно 150 тисяч науковопедагогічних працівників) в Україні працюють у закладах вищої освіти. Щорічно ними реалізуються більше 20000 наукових проектів [11].

Більша частина отриманих результатів наукових досліджень не впроваджуються у виробництво, а залишаються у вигляді заключних звітів на полицях бібліотек.

В першу чергу це пояснюється відсутністю фінансових ресурсів як у ЗВО, так і у держави.

Як показують аналітичні дослідження, публікаційна активність науковців, яка 3 кожним роком підвищується, не впливає на рівень впровадження результатів наукової діяльності, що проводиться у ЗВО.

Науковці витрачають багато часу та грошей на підготовку монографій, публікацію статей у збірниках, які включені до міжнародних наукометричних базах, але реальні результати використання розробленої новітньої продукції та технологій у виробництві відсутні. 
Патентна активність науковців також не має значного впливу на рівень впровадження результатів наукової діяльності. Як показують реалії сучасності, отримання патенту науковцем не гарантує його реальне використання у виробництві інноваційної продукції шляхом купівлі охоронного документа бізнесовими структурами.

Головною причиною такого становища більшість фахівців вважають відсутність ефективної, науково-обгрунтованої системи управління інноваційною діяльністю.

Проаналізувавши напрями державної політики в області наукової діяльності, можна 3 впевненістю стверджувати, що фінансування здійснюється за не зовсім зрозумілою схемою.

Тобто Україна фінансує не процес виконання наукової діяльності, а направляє гроші на підтримку в належному стані наукових інститутів, переказуючи кошти на опалення, інші комунальні послуги, утримання будівель тощо, що негативно відображається на науковому процесі. Кошти йдуть не дослідникам, а витрачаються на фінансування різного роду структур. Невисокий рівень оплати праці в науковій сфері сприяє відтоку кваліфікованих спеціалістів з України.

За останні десятиріччя українська наука зазнала значних змін. Колись одна $з$ провідних країн світу з чисельними школами, традиціями, матеріально-технічними базами, Україна перетворилась на державу, в якій всі спроби на підвищення ефективності інноваційної діяльності закінчуються занепадом.

Однак просте збільшення обсягів фінансування відчутних результатів не принесе. Історично система фінансування науки в Україні побудована таким чином, що держава фінансує комунальні платежі науководослідних інститутів і сплачує мізерні зарплати співробітникам.

Як було зазначено вище, прикладом бізнес-інкубаторів, які зарекомендували себе в якості ефективних інноваційних організацій, є Кембриджський технопарк та технополіс «Силіконова долина». Зарубіжні країни динамічно розвивають інноваційну діяльність за моделлю потрійною спіралі. В Україні, на жаль, окрім гасел, що потрібно створювати та впроваджувати інновації у всі сфери життя суспільства, на практиці спроби переходу на інноваційний шлях розвитку закінчуються крахом. Всі відомі світові підходи до управління інноваційною діяльністю в Україні не реалізовані.

Сучасні міжнародні тенденції свідчать про важливість розробки нової методології стійкого проектно-орієнтованого управління діяльністю організацій на основі «Магічного трикутника», який гармонізується 3 соціальними, економічними, екологічними аспектами як факторами оточення проекту. 
Існує 17 цілей в області стійкого розвитку людства до 2030 року, які потрібно враховувати при розробці продукту проекту. Наведені цілі можна розподілити за наступними рівнями. Рівень держави обумовлює ліквідацію бідності і голоду, гарне здоров'я і добробут населення, гендерну рівність, індустріалізацію, інновації, інфраструктуру. Також цей рівень враховує забезпечення стійкості міст і населених пунктів, боротьби зі змінами клімату, збереження морських екосистем і екосистем суходолу, миру, правосуддя та ефективних інститутів.

На рівні університету передбачається якісна освіта; інновації та інфраструктура.

Рівень бізнесових структур включає недороговартісну і чисту енергію, індустріалізацію, інновації, інфраструктуру, гідну роботу і економічне зростання, відповідальне споживання і виробництво.

Міжнародне співтовариство ставить в якості головної цілі організацій, які займаються управлінням проектами та програмами, партнерство в інтересах стійкого розвитку.

Сучасні світові підходи до управління інноваційною діяльністю викликають радикальні трансформації, пов'язані з вирішальним значенням університетів для інноваційного розвитку, що призводить до економічного зростання держави, підвищення добробуту населення та підтримки бізнесу.

На міжнародному рівні простежується зміна цілей університетів окрім наукової та освітньої, виникає ціль економічної активності. Ця мета включає розробку та трансфер технологій, комерціалізацію продуктів академічної науки, управління інтелектуальною власністю 3 метою отримання прибутку, створення нових бізнесових структур.

В залежності від кількості цілей, заклади вищої освіти розподіляються на: університет 1.0, 2.0, 3.0, 4.0. Університет $1.0 €$ тільки освітнім інститутом. Університет 2.0 надає освітні послуги та проводить наукові дослідження Метою університету $3.0 €$ освітня, наукова діяльність та комерціалізація знань (інновації). Університет 4.0 спеціалізується на проведенні освітньої, наукової, інноваційної діяльності, а також формуванні креативного середовища [11].

Найбільш перспективною $з$ точки зору інноваційного розвитку $\epsilon$ модель «університет 4.0». Ця модель дає змогу, окрім підготовки професійних фахівців, здатних вирішувати задачі на основі технології блокчейн, сформувати прогресивне середовище знань та інновацій, яке дозволить отримати ефективний результат від здійснення інноваційної діяльності.

Університет у даному випадку позиціонується як корпоративний суб'єкт економіки знань [12]. Для України проблема розширення цілей університету є соціально значущою, оскільки саме трансфер технологій та комерціалізація знань шляхом реалізації продукту інноваційної діяльності сьогодні відіграє вирішальну роль у модернізації соціально-економічного становища держави. 
Актуальність дослідження обумовлена сучасним несприятливим інноваційним кліматом в державі, який сформований в умовах непрацюючого державного регулювання інноваційної сфери, стрімкого занепаду української науки, іï фактичної відірваності від підприємництва.

У такій ситуації виникає нагальна необхідність розробки нових теоретичних і методологічних підходів та механізмів на основі передового досвіду розвинутих країн, які б дозволили підвищити ефективність взаємодії учасників інноваційної діяльності, а саме закладів вищої освіти, що займають найбільшу частку в сфері проведення наукової діяльності у державі. Потрібно провести зміну концепції управління організаційною та фінансовою складовою інноваційної діяльності, а саме - переходити до застосування сучасних методологій управління науковою діяльністю закладів вищої освіти в Україні, враховуючи провідний міжнародний досвід.

Висновки. Інтенсивне проведення досліджень та розробка на їх основі новітніх технологій, вихід із ними на світові ринки та розгортання міжнародної інтеграції в науковій сфері фактично вже стали стратегічною моделлю економічного зростання для розвинених країн. Причому інтелектуальні ресурси спільно з новітніми технологіями не тільки визначають перспективи економічного зростання, але і служать показником рівня незалежності й добробуту країни.

На підставі аналізу чисельних досліджень, проведених вітчизняними та іноземними фахівцями, доведено, що основним драйвером соціально-економічного розвитку суспільства є інноваційна діяльність. Статистика продемонструвала негативні результати щодо проведення наукових досліджень та їх впровадження в Україні в останні десятиріччя. В основі такого становища лежать дві основні причини - економічна (недостатнє фінансування) й організаційна (неефективне управління державними закладами).

\section{ЛIТЕРАТУРА}

1. Bushuyev, S., Verenych, O. Organizational maturity and project: Program and portfolio success (Book Chapter), Developing Organizational Maturity for Effective Project Management, 2018, P. 2-24.

2. Piterska, V., Lohinov, O. and Lohinova, L. (2019).Mechanism for forming an effective portfolio of research projects of institution of higher education, Innovative technologies and scientific solutions for industries, 3 (9), pp. 99-108. https://doi.org/10.30837/25229818.2019.9.099. 
ВІСНИК

ОДЕСЬКОГО НАЦІОНАЛЬНОГО

МОРСЬКОГО УНІВЕРСИТЕТУ

№ 2 (65), 2021
HERALD

OF THE ODESSA NATIONAL

MARITIME UNIVERSITY

3. Логинов, О.В. Проектно-ориентированное управление образовательной деятельностью ВУЗов: дис. ... канд. техн. наук: 05.13.22 / Логинов Олег Владимирович. Одесса, 2016. 186 c.

4. Бушуева, Н.С. Модели и методы проактивного управления программами организачионного развития / Н.С. Бушуева. К.: Наук. світ, 2007. 270 c.

5. Piterska, V., Lohinov, O. and Lohinova, L. (2019) Portfolio method of scientific activity management of higher education institutions, Innovative technologies and scientific solutions for industries, (2 (8), pp. 86-96. doi: 10.30837/2522-9818.2019.8.086.

6. Bushuyev, S., Murzabekova, A., Murzabekova, S., Khusainova, M. Develop breakthrough competence of project managers based on entrepreneurship energy, Proceedings of the 12th International Scientific and Technical Conference on Computer Sciences and Information Technologies, CSIT 2017, P. 11-16. DOI: 10.1109/STC-CSIT.2017.8099420

7. Bushuyev, S., Bushuev, D., Bushuyeva N., Kozyr B. Information technologies for project management competences development on the basis of global trends, Information technology and learning tools, vol. 68, No. 6, 2018, P. 218-234. DOI: https:// doi.org/ 10.33407/itlt.v68i6.2684

8. Piterska, V.M., Rudenko S.V., Shakhov A.V. Development of the Method of Forming of the Architecture of the Innovation Program in the System "University-State-Business» / V.M. Piterska, S.V. Rudenko, A.V. Shakhov // International Journal of Engineering \& Technology (UAE). 2018. Vol. 7 (4.3). P. 232-239.

9. Piterska, V.M., Shakhov, A.V. Development of the Methodological Proposals for the Use of Innovative Risk-Based Mechanism in Transport System / V. Piterska, A. Shakhov // International Journal of Engineering \& Technology (UAE). 2018. Vol. 7 (4.3). P. 257-261.

10. Shakhov, A., Piterska, $V$. The development of the risk management mechanism for innovation project / A. Shakhov, V. Piterska // EUREKA: Physics and Engineering. Company «Scientific Route», Tallin. Number 3. 2018. P. 12-20.

11. Пітерська В.М. Проектно-орієнтований підхід в управлінні науковою діяльністю в Україні / В. М. Пітерська // Вісн. Одес. начи. морського ун-ту. 2015. № 2 (44). С. 186-195. 
ВІСНИК

ОДЕСЬКОГО НАЦІОНАЛЬНОГО

МОРСЬКОГО УНІВЕРСИТЕТУ

№ 2 (65), 2021
HERALD

OF THE ODESSA NATIONAL

MARITIME UNIVERSITY

12. Piterska, V., Kolesnikov, O., Lukianov, D., Kolesnikova, K., Gogunskii, V., Olekh, T., Shakhov, A., Rudenko, S. Development of the Markovian model for the life cycle of a project's benefits / V. Piterska, O. Kolesnikov, D. Lukianov, K. Kolesnikova, $V$. Gogunskii, T. Olekh, A. Shakhov, S. Rudenko // Eastern-European Journal of Enterprise Technologies, 2018, 5/4 (95), pp. 30-39.

13. Kosenko, V., Persiyanova, E., Belotskyy, O. and Malyeyeva, $O$. Methods of managing traffic distribution in information and communication networks of critical infrastructure systems, Innovative technologies and scientific solutions for industries, (2 (2), 2017. P. 48-55. DOI: https://doi.org/10.30837/25229818.2017.2.048

14. Питерская, В.М. О проблемах развития научно-технологических парков в Украине / В.М. Питерская // Проблемь техники. № 3, 2012. С. 104-114.

15. Кононенко, И.В. Оптимизачия содержания проекта по критериям прибыль, время, стоимость, качество, риски [Текст] / И.В. Кононенко, М.Э. Колесник // Восточно-Европейский журнал передовых технологий. 2012. № 1/10 (55). С. 13-15.

\section{REFERENCES}

1. Bushuyev, S., Verenych, O. Organizational maturity and project: Program and portfolio success (Book Chapter), Developing Organizational Maturity for Effective Project Management, 2018, P. 2-24.

2. Piterska, V., Lohinov, O. and Lohinova, L. (2019). Mechanism for forming an effective portfolio of research projects of institution of higher education.Innovative technologies and scientific solutions for industries, (3 (9), pp. 99-108. https://doi.org/10.30837/25229818.2019.9.099.

3. Loginov, O.V. Proyektno-oriyentirovannoye upravleniye obrazovatel'noy deyatel'nost'yu VUZov: dis. ... kand. tekhn. nauk 05.13.22 [Project-oriented management of educational activities of universities. Candidate eng. sci. diss. (Ph. D.)]. Odessa, 2016. 186 p.

4. Bushuyeva, N. Modeli $i$ metody proaktivnogo upravleniya programmami organizatsionnogo razvitiya [Models and methods of proactive management of organizational development programs], Kiev, Naukovii svit, 2007, 270 p.

5. Piterska, V., Lohinov, O. and Lohinova, L. (2019) Portfolio method of scientific activity management of higher education institutions, Innovative technologies and scientific solutions for industries, (2 (8), pp. 86-96. doi: 10.30837/2522-9818.2019.8.086. 
6. Bushuyev, S., Murzabekova, A., Murzabekova, S., Khusainova, M. Develop breakthrough competence of project managers based on entrepreneurship energy, Proceedings of the 12th International Scientific and Technical Conference on Computer Sciences and Information Technologies, CSIT 2017, P. 11-16. DOI: 10.1109/ STC-CSIT.2017.8099420

7. Bushuyev, S., Bushuev, D., Bushuyeva N., Kozyr B. Information technologies for project management competences development on the basis of global trends. Information technology and learning tools, vol. 68, № 6, 2018, P. 218-234. DOI: https://doi.org/ 10.33407/itlt.v68i6.2684

8. Piterska, V.M., Rudenko S.V., Shakhov A.V. Development of the Method of Forming of the Architecture of the Innovation Program in the System "University-State-Business» / V.M. Piterska, S.V. Rudenko, A.V. Shakhov // International Journal of Engineering \& Technology (UAE). 2018. Vol. 7 (4.3). - P 232-239.

9. Piterska, V.M., Shakhov A.V. Development of the Methodological Proposals for the Use of Innovative Risk-Based Mechanism in Transport System / V. Piterska, A. Shakhov // International Journal of Engineering \& Technology (UAE). 2018. Vol. 7 (4.3). P. 257-261.

10. Shakhov, A., Piterska, $V$. The development of the risk management mechanism for innovation project / A. Shakhov, V. Piterska // EUREKA: Physics and Engineering. Company Scientific Route, Tallin. Number 3. 2018. P. 12-20.

11. Piterskaya, V.M. Proektno-oriyentovanyy pidkhid $v$ upravlinni naukovoyu diyal'nistyu $v$ Ukrayini/ [Project-oriented approach in the management of scientific activity in Ukraine]. Visn. Odessa. nat. maritime university [Bulletin of the Odessa National Maritime University], Odessa, 2015. № 2 (44). P. 186-195.

12. Piterska, V., Kolesnikov, O., Lukianov, D., Kolesnikova, K., Gogunskii, V., Olekh, T., Shakhov, A., Rudenko, S. Development of the Markovian model for the life cycle of a project's benefits / $V$. Piterska, O. Kolesnikov, D. Lukianov, K. Kolesnikova, V. Gogunskii, T. Olekh, A. Shakhov, S. Rudenko // EasternEuropean Journal of Enterprise Technologies, 2018, 5/4 (95). P. 30-39.

13. Kosenko, V., Persiyanova, E., Belotskyy, O. and Malyeyeva, O. Methods of managing traffic distribution in information and communication networks of critical infrastructure systems, Innovative technologies and scientific solutions for industries. 2 (2), 2017. P. 48-55. DOI: https://doi.org/10.30837/2522-9818. 2017.2.048 
ВІСНИК

ОДЕСЬКОГО НАЦІОНАЛЬНОГО

МОРСЬКОГО УНІВЕРСИТЕТУ № 2 (65), 2021
HERALD

OF THE ODESSA NATIONAL

MARITIME UNIVERSITY № 2 (65), 2021

14. Piterskaya, V. O problemakh razvitiya nauchno-tekhnologicheskikh parkov $v$ Ukraine [On the problems of the development of scientific and technological parks in Ukraine], Problems of technology [Problemy Tekhniky], Odessa, 2012. № 3. P. 104-114.

15. Kononenko, I. Optimizatsiya soderzhaniya proyekta po kriteriyam pribyl', vremya, stoimost', kachestvo, riski [Optimization of the project content according to the criteria of profit, time, cost, quality, risks], Eastern-European Journal of Enterprise Technologies, № 1/10 (55), 2012. P. 13-15.

Стаття надійшла до редакиії 20.05.2021

Посилання на статтю: Пітерська В.М. Механізми проектноорієнтованого управління закладами вищої освіти в рамках інноваційних програм // Вісник Одеського національного морського університету: Зб. наук. праць, 2021. № 2(65). C. 173-185. DOI 10.47049/ 2226-1893-2021-2-173-185.

Article received 20.05.2021

Reference a JournalArtic: Piterska Varvara. Mechanisms of projectoriented management of higher education institutions within the framework of innovative programs // Herald of the Odessa national maritime university. 2021, № 2(65). 173-185. DOI 10.47049/ 2226-1893-2021-2-173-185. 